\title{
TRENDS IN MARRIAGE AND DIVORCE LAW OF WESTERN COUNTRIES*
}

\author{
MAX RHEINSTEIN $\dagger$
}

In a world of profound and accelerating change, the institution of marriage has been standing out as a pillar of stability. Yet, it has not remained completely unaffected and those changes which have occurred have been reflected in the legal rules which have grown up to guarantee and regulate the institution. The social and legal phenomena which have appeared in the course of this process have varied not only between different countries, but even between the states of our own nation. If we analyze these differences from a long-range point of view, we can find that they reflect two major trends, which are related to each other, viz., those of secularization and liberalization. These trends have not been operative everywhere with equal strength and they have hardly anywhere been unopposed. From this interplay of forces there have emerged varying compromises, often of an uneasy and unstable nature.

There are several countries in which, in accordance with the once universal rule, marriage is still treated as indissoluble in any way other than death, which means, in other words, that the institution of divorce does not exist. Thus is the situation in such strictly Catholic countries as Italy, Spain, the Irish Republic, Argentina, Brazil, or Quebec. ${ }^{1}$

In the majority of countries, the institution of divorce has come to be admitted, but in many it is dominated by an idea which was developed in the ecclesiastical courts in a different context. The ecclesiastical courts of the Catholic Church as well as of the various Protestant churches have long known the institution of judicial separation (separatio a mensa et thoro), in which a party to a marriage was absolved from his duty to live with the other without being freed, however, from the tie of the marriage, which would thus continue to prevent any remarriage during the lifetime of the other spouse. On its face a decree of separation would do no more than authoritatively pronounce that the petitioner's refusal to live with the other party is not sinful. The decree is also of practical importance because it lays the foundation for a claim of support where it has been obtained by the wife, or, where it has been obtained by the husband, makes clear that he is under no duty

- A paper presented at the fifteenth annual Groves Conference on Marriage and Divorce, held on April 22, 1952, in Durham, N. C.

tDr.utr.iur. 1924, University of Munich. Max Pam Professor of Comparative Law, University of Chicago Law School.

${ }^{2}$ Cf. Bergmann, Ehescheidung und Ehetrennung, 2 Franz Schlegelderger, Rechtsvergleichendes HANDWOERTERBUCH 7I6 (1929); Simson, Les transformations du droit européen du divorce depuis dix ans, I Revue International de Droit Comparé 23, 25 (I949); Adolf F. Schnitzer, Vergleichende RECHTSLEHRE 334 (1945). 
to furnish support to the wife. In view of this character of the proceedings it became established that no decree of judicial separation would be granted to a party to a marriage unless the other had been guilty of a serious breach of marital duty, such as adultery on the wife's part, or extreme cruelty or abandonment on that of the husband. It was also established that a spouse should not be entitled to a decree of separation unless he had conducted himself as a true and faithful husband or wife, as the case might be. A judicial separation was thus to be a punishment for a guilty spouse and a reward for an innocent. In the context this approach was thoroughly sensible. Strangely, however, it was transferred in many places to the different proceedings in which ecclesiastical or, more commonly, secular courts were to decide whether the parties to a marriage which had broken down were to be freed from its tie and thus to be restored to the freedom of remarriage. Divorce thus was predicated upon the notion of guilt, to be granted only in the case of some serious misconduct by one party against another who has conducted himself with marital exemplariness. The divorce statutes thus came to contain lists of so-called "grounds for divorce"2 as well as to establish what has become known as the principle of recrimination. The latter, however, was not adopted or preserved generally and the statutory lists of divorce vary greatly, from the narrowness of such laws as that of New York, where adultery still constitutes the only ground, ${ }^{3}$ to the liberalism of such laws as those of California ${ }^{4}$ or France, ${ }^{5}$ where a divorce is obtainable upon the ground of "cruelty" or some equivalent concept applied by the courts in such a way as to cover all, or almost all, conduct of a spouse which is felt to be offensive by the other or even simply declared by the latter to be so. The general trend over the last one hundred and fifty years, at least until recently, has been to enlarge the statutory list of grounds, or, by judicial practice, to broaden their meaning, or both. Still, such laws limit divorce to cases of guilty conduct and thus preclude divorce in those cases where a marriage has become unbearable or distasteful without either party having been guilty of any special marital misconduct. Such a factual breakdown may occur not only in the case of one party's insanity, but also in those other situations where the spouses have come to hate, or simply to tire of, each other. Statutes allowing a divorce in such cases of mere factual breakdown constitute a minority. Incurable insanity of a spouse, it is true, has been admitted by a steadily increasing number of laws, ${ }^{6}$ but divorce by mutual agree-

\footnotetext{
${ }^{2}$ For typical catalogues of this kind see England: Matrimonial Causes Act, 1937, I EDw, 8 \& I Geo. 6, c. 57; Germany: Marriage Law of July 6, 1938, [1938] ReichscesetzblatT I, 807, re-cnacted by the Allied Control Council as Control Council Law No. I6 of Feb. 20, I946; or Ill. Rev. Stat. c. 40, 5I (I95I).

${ }^{3}$ N. Y. Civ. Prac. Acr $§ 1147$.

Cal. Civ. Code $\$ \$ 92,94$ (1949).

${ }^{5}$ Crvil Code art. 23r: Either party to a marriage may sue for a divorce on the ground of excesses, cruel treatment by, or seriously offensive conduct (injures graves) of, the other.

${ }^{6}$ See, for instance: Denmark: Marriage Law of June 30, x922, $\$ 63$ (3 years); Germany: Marriage Law of July 6, 1938, [1938] R'eichsgesetzblatt I, 801, re-enacted as Control Council No. i6 of Feb. 20, 1946, \$45 ("A party to a marriage may apply for a divorce if the other is insane, provided that the disease has reached a stage at which the intellectual community of the spouses has been destroyed and the restoration of this community cannot be expected"); England: Matrimonial Causes Act, 1937, r Evw.
} 
ment or because of one party's "insurmountable aversion" against the other can still be found only in few laws (the Scandinavian countries, Switzerland, Belgium, and in a steadily growing number of jurisdictions in this country), ${ }^{7}$ although it was provided for in the earliest of all modern divorce laws, the Prussian Decree of 1752. As a characteristic feature of our field we also find in many places a discrepancy between a theoretically strict law and actual practices thereunder, achieved through the use of more or less generally indulged collusive practices. Illustrations are afforded by such typical states of our country as Illinois, and also by a number of foreign countries such as France. ${ }^{\circ}$

The divergency of approaches has also found expression in vacillating shifts within the same country; here France stands as typical. In keeping with the

8 \& I GEo. 6, c. 57, $\$$ I76(d) (5 years); Finland: Marriage Law of June 13, I929, \$75 (normally 3 years); Iceland: Marriage Law of June 27, I92x; Norway: Law on Conclusion and Dissolution of Marriage of May 15, I918, c. 5, $\$ 53$ (3 years); Portugal: Decree Introducing Divorce of Nov. 3, 1910, art. 4, No. 7 (3 years); Sweden: Marriage Law of June II, I920, c. II, \$I3 (3 years); Switzerland: Civil Code of Dec. 10, 1907, art. I4I (3 years). In the United States, insanity has been admitted as a ground for divorce in 27 states. Cf. Fowler V. Harper, Problems of the Family 390 (1952).

"In Sweden the significant provisions are contained in Chapter II of the Marriage Law of June II, rg20 which reads as follows:

"§r. Where the parties to a marriage cannot continue to live together because of a thoroughgoing and permanent discord and where they have agreed to live separate, they are entitled to a judicial decree of separation.

"\$2, par. 2. Where in consequence of the diversity of their characters and attitudes toward life or because of other reasons a thoroughgoing and permanent discord has arisen between the parties to a marriage, either party is entitled to a judicial decree of separation unless his own conduct or other special circumstances render it proper that he be required to continue to live with the other party.

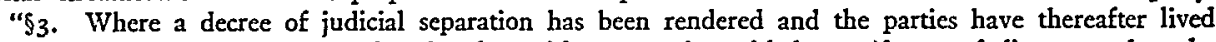
for one year separate and apart of each other, either party is entitled to a decree of divorce, unless the parties have resumed their cohabitation."

The laws of Denmark (Law of June 30, 1922 Concerning the Conclusion and Dissolution of Marriage, c. $6, \$ \$ 52,53$ (par. 2), 54: divorce by administrative decree after six months' separation); Finland (Marriage Law of June $13,1929, \mathrm{Pt}$. III, c. $1, \$ 76$ : divorce after 2 years of factual separation). Iceland (Law of June 28, 1921, $\$ \$ 51$ et seq.) and Norway (Law of May 15, 1918, Concerning Marriage and Divorce, c. 5, $\$ \$ \mathrm{I}, 43$ : divorce by administrative decree) are similar.

Under the Swiss Civil Code of Dec. I0, I907, art. 142, either party is entitled to a judicial decree of divorce "where the marital relation has been so deeply shattered that the parties cannot be properly expected to continue their marital community."

The Belgium Code, which is the Code Napoleon, as modified by local legislation, has preserved the provision of Article 233 of the original text, which was abolished in France in I8I6, and which reads as follows: "The mutual and serious agreement of the parties, if it has been declared in the form prescribed by law and has been preceded by their examination as provided by law, constitutes proof of the fact that life in common is unbearable to them and that there exists between them a valid cause for divorce." The procedure is so much more cumbersome and time consuming than that in cases of divorce upon the ground of cruelty, that divorce by mutual consent seems to be be rarely used.

In this country a divorce can be obtained in 16 jurisdictions (Arizona, Arkansas, District of Columbia, Idaho, Kentucky, Louisiana, Maryland, Nevada, North Carolina, Rhode Island, Texas, Utah, Vermont, Washington, Wisconsin, and Wyoming) if the parties have lived factually separated from each other for a stated period of time, and in four states (Minnesota, North Dakota, Virginia, and West Virginia) if a judicial separation is not followed by a reconciliation ( $c f$. Fowler V. Harper, Problems of the FAMILY 658-659 (1952)).

${ }^{3}$ See note 26 , infra.

${ }^{-}$In the latter country it seems to be not uncommon that the offensive letter which is to constitute the ground of injure grave is agreed upon between the parties. 
Catholic character of the state, marriage was treated as indissoluble all through the ancien régime. The Revolution of 1789 brought the extremely liberal divorce law of 1792 , which even provided the possibility of the dissolution of a marriage upon the mutual agreement of the parties. Through Napoleon's Civil Code of 1804 divorce was made more difficult, and under the Bourbon restoration, the wheel was turned back fully and divorce was completely abolished in $18 \mathrm{r} 6$, not to be reintroduced again until the Third Republic's liberal, but cautious, law of r884. A practice of continuously increasing liberalism was again reversed by the legislation of Marshal Pétain's Vichy government, but this, in turn, was repealed upon the liberation of France in $1945 .^{10}$

Yet, in spite of all divergencies and vagaries, modern developments in the field of marriage and divorce have been characterized by the two trends of secularization and liberalization. In order to understand and evaluate their impact, it is necessary to sketch the state of affairs against which these trends have been operating and the ways in which it came into being.

Today, we take it for granted, at least in the Occident, that marriage is subject to regulation by the state. This notion has not always prevailed, however; as a matter of fact, it is of fairly recent origin.

Throughout antiquity, the state kept aloof from regulating so personal and intimate a relationship as marriage, which was regarded as a distinctly private affair of the individuals concerned. Not that the individual would have been free to enter upon any kind of sexual relationship of his own free choosing. There were religious taboos probably everywhere and in the case of some people, especially the Hebrews, religion developed an elaborate marriage code ${ }^{11}$ which, under the theocratic form of government, was hardly distinguishable from state regulation. There were also the set patterns of the mores, which effectively stabilized kinship and sex relations and which could not be flouted without serious social sanctions. But the state, its laws, and its courts were concerned with marriage only indirectly. Rome presents not only an important but also a typical example. For a variety of purposes it was important for the courts to know whether or not a particular relationship constituted a marriage. Of Roman society it can properly be said that it was composed not so much of individuals as of families. ${ }^{12}$ With some justification it can be asserted that down into the times of the Empire, private rights and duties, such as property title, contractual claims or obligations, pertained solely to the heads of households, the patres familias. It thus became necessary to ascertain who belonged to a household as the wife or child of a pater familias so as to de-

${ }^{10}$ Decree of April I2, 1945. On the history of French divorce law, see Jacob, Problems of Divorce in France Incident to the Statutes of $194 \pi, 28$ IowA L. REv. 298 (1943).

${ }^{11}$ Lev. 18:6-23; 20:10-21; Num. 5:11-31; Deut. 22:13-30; 23:1-8; 24:I-4.

${ }^{13}$ On Roman marriage and family, see James Bryce, Marriage and Divorce Under Roman and English Latv, 2 Studies IN History aNd JURISPRUdence 381 (190r), reprinted in 3 Selected Essays in ANglo-American Legat History 782 (1909); Frederick P. Walton, Introduction to Roman Law 70 (4th ed. 1920); Charles R. Noyes, The Institution of Property 122 (1936); William W. Buckland, A Textrook of Roman law from augustus to Justinian jor (2d ed. 1932); Fritz Schulz, Classical Roman law io3 (I95I). 
termine, for instance, to whose acquisitions he would acquire title or for whose torts he would be liable or, quite particularly, who would be entitled to his property after his death. As monogamous marriage was established by the mores as the basis of a family relationship, it was necessary to know in a particular case whether or not a marriage had been concluded or terminated. However, the law not only failed to prescribe any particular formalities for the conclusion of a marriage, but also refrained from either establishing impediments to marriage beyond the ancient incest taboos or limiting in any way individual freedom at any time to dissolve a marriage or even requiring for such dissolution the permission or cooperation of any court or other governmental agency. In earlier times this freedom of divorce pertained, it is true, only to men, but during the late republican period it also came to be enjoyed by women. As divorces became increasingly frequent, imperial legislation found it necessary to some extent to regulate the effects of a divorce upon the parties' property rights against each other, and such legislation was sought to be used as an indirect means to discourage divorces, but never to its very end did the Roman state try to abolish the freedom of private parties to conclude and to terminate their marriages as their own affairs, upon their own volition, and through their own act. No court decree or other act of government was ever required in Rome as a constituent element of a divorce and never was there engendered the idea that a divorce would not be possible except upon "cause."

Neither in Rome nor anywhere else in the ancient world did this complete absence of legal restraints upon divorce result in a breakdown of the institutions of marriage or the family. Both indeed are social institutions rather than legal ones, even in our society, where the state has assumed such a large role in their regulation. The duties which are incumbent upon marriage partners have their guarantee and sanction in the moral or religious conscience of the parties, in established traditions, and in social conventions. Only in marginal situations does the law step in with its clumsy arsenal of courts, sheriffs, and jailors, to supplement the sanctions of the mores, and to clarify doubtful situations. In the more homogeneous societies of the past the social sanctions were sufficiently effective to maintain those patterns of family relationships which the folkways had developed and which the society in question regarded as the proper ones. In the mores of the Roman Republic in particular, matrimony and the family occupied a position of high dignity and a man's action would not easily be condoned if he cast off his wife without grave reason, whatever legal freedom he might have had to do so. In the late Republic and the early Empire, the strictness of the old Roman morals was considerably relaxed and especially among the upper classes of the capital city free divorce became socially acceptable and was practiced freely; but even then this freedom does not seem to have resulted in a breakdown of the family.

The same absence of state regulation of marriage and divorce which existed in Rome, we find among the Germanic peoples ${ }^{13}$ who entered the scene of history

${ }^{13}$ Cf. Rudolf Huebser, A History of Germanic Private Law 588 (Philbrick's transl. igr8). 
in the last centuries of antiquity. Indeed, their state, just as that of other primitive peoples, in so far as it existed at all, was much too rudimentary to concern itself with such matters as marriage and divorce. The conclusion of a marriage, for which the law did not require any formalities, was a transaction between the groom and the bride's family. No legal rule prevented the husband from freely repudiating his wife, but before availing himself of that freedom, he might well consider whether he might not thereby endanger his standing with the community and whether he might not find himself confronted with the unpleasant choice between a blood feud with the repudiated wife's sib, and the possibility of buying it off by some heavy payment. In the later Frankish period social disapproval of divorce seems to have been less strong than it is said by Tacitus to have been in earlier days, and women also seem to have acquired a social status which allowed them to walk out of a marriage which had become distasteful.

The complete absence of any formal regulation of marriage and divorce, which was characteristic for Rome as well as for the Germanic peoples, was radically changed by that third element which entered into the making of the Middle Ages and thus of our modern world, i.e., Christianity. In the Jewish setting, in which it originated, all aspects of life were permeated with religious significance and under the theocratic form of government religious regulation inevitably was to be state regulation, too. But there was surprisingly little authoritative regulation of marriage. While the strictness of the religious code of sexual mores distinguished the Jews from most other peoples of the ancient Orient, the conclusion of a marriage was not subject to much regulation apart from the incest taboos of the Book of Leviticus. It was a private affair the validity of which did not depend upon the observation of any formalities. Divorce, too, was freely permissible to the husband, subject only to informal censure by the community. An entirely new element was injected, however, by Christianity, viz., the idea that marriage is a sacrament and that, for that reason, it is indissoluble by man. The rise of this notion is not entirely clear just as it is doubtful what Jesus meant by those Scriptural passages upon which the doctrine came to be based. ${ }^{14}$ Quite possibly he meant only that a man who wished to attain the exemplary religious life should not avail himself of that possibility of freely repudiating a wife which was open to him under the Mosaic law. By that law no more was required of him than that he gave her, as evidence of her freedom from marriage ties, his letter of divorcement. Divorce as it has come to be widely understood in our days, viz., in the sense of a more or less amicable parting of the ways of two partners of equal status, was hardly a problem in Jewish society of Jesus' days. Yet, whatever Jesus may have meant by his sayings, they were made the foundation of the new doctrine of the sacramental character of marriage and its consequential indissolubility. This doctrine was both new and sublime.

\footnotetext{
${ }^{14}$ Matt. 5:3I-32; Mark 10:9-12; Luke 16:18.
} 
A sacrament, as understood in Christian doctrine, is a visible sign which, by its very operation, confers grace on him who worthily receives it. ${ }^{15}$ It was not until the sixteenth century that the Church declared celebration before a priest to be essential for the validity of a marriage. The sacrament of matrimony is thus administered not by the priest to the parties but by the parties to each other. ${ }^{16}$ As the marriage is not consummated until the parties have had sexual intercourse, ${ }^{17}$ the doctrine of the sacramental nature of matrimony means that man's most animalic act is sanctified and elevated to the level of the divine and that the union thus created is to be a constant bridge between this world and the Kingdom of Heaven. This sublime idea also, of course, implies the demand that the parties to the marriage at all times strive to live up in their relationship to that level which renders them worthy of the divine grace. It is this demand which implies the indissolubility of the union by any act of the parties which would, of necessity, indicate their unworthiness of the sacrament.

The demand is a lofty one, not always easy to live up to, especially for one who is not fortified by faith and belief in the total body of the creed of the Church. But, while the Church was the dominant force in Western society, it formalized its demand as a part of that peculiar body of rules which, although not the law of the state, were nevertheless law in the sense of a body of rules for human behavior which are authoritatively and formally pronounced and expounded by courts, and enforced by a special staff of officers. Through this, canon law, as applied in its ecclesiastical courts, the Church for the first time in the Western world elaborated and established a formalized regulatory system with respect to marriage, both as to the requirements for its valid conclusion and the duties which it entails for the parties. An essential role in this body of ecclesiastical law was played by the principle of indissolubility of marriage and the heavy duties implied.

To render this body of rules effective and, particularly, to enforce its principle of indissolubility of marriage, was no easy task for the Church. It took centuries until the postulates became generally accepted. Not only had the Church to repress the resistance and urge of unruly peoples who had not been accustomed to such rigid norms, but also, in its effort to exercise jurisdiction through its courts, the Church came into conflict with the new power of the temporal state that was nascent everywhere upon the ruins of the ancient empire of the Romans. Yet, in spite of all difficulties the Church succeeded in making its courts and its matri-

${ }^{15}$ The normal definition of sacrament is found in Hugh of St. Victor's (Iog6-II4I) De Sacramentis (Book I, Part IX, Cap. II): "Sacramentum est corporale vel materiale elementum foris sensibiliter propositum, ex similitudine repraesentans, et ex institutione significans, et ex sanctificatione continens, aliquam invisibilem et spiritualem gratiam." The Anglican Catechism defines it as follows: "An outward and visible sign of an inward and spiritual grace given unto us; ordained by Christ himself, as a means whereby we receive the same, and a pledge to assure us thereof."

10 "Matrimony is a lawful and exclusive contract by which a man and a woman mutually give and accept a right over their bodies for the purpose of acts which are in themselves suitable for the generation of children." Timothy L. Bouscaren, S. J., and A. C. Ellis, S. K., Canon Law, A Text and Commentary 399 (x946); cf. Codex Juris Canonici, Canons 1012, 1013, 108r.

${ }^{17}$. Codex Jurus Canonici, Canon ior5, 81 . 
monial law effective everywhere from Scandinavia to Sicily and from Portugal to the Territory of the Teutonic Knights on the shores of the Baltic. Some concessions had to be made. While divorce remained excluded, annulment became possible to such an extent that it came to satisfy a large part of the demand for a way out of a marriage that had become distasteful. The most effective means in that respect was created through the continuous expansion of the scope of prohibited degrees which grew to be so comprehensive that it was a rare case in which it would not have been possible to discover an impediment once a termination of a marriage was sought. However, in decisive contrast to the pre-Christian state of affairs, it was now necessary, for the termination of a marriage, to institute formal proceedings in a court, to submit to an official investigation, and to obtain a formal decree. A marriage could no longer be terminated by the informal, private, extra-judicial act of the parties, and this principle of the necessity of an authoritative act of a court or some other official agency has remained a part of our law ever since. It was established, together with the principle of authoritative, formalized, "legal" regulation of marriage, in the course of that portentous trend which had led from informal regulation through the folkways and mores to control and regulation by the institutionalized religion of the Catholic Church.

That trend found its completion in the establishment by the Council of Trent ${ }^{18}$ of the rule that not even the conclusion of a marriage should any longer be possible by the parties' private act, without the official cooperation of a functionary of the Church. However, before that stage of completion was reached, there had already set in that new trend of secularization of marriage in which regulation by the State came to be substituted for that by the Church and which in its course came to engender the concomitant trend of liberalization, by which the principle of indissolubility of marriage came to be undermined or even nullified.

This trend of secularization of marriage can be traced to three main roots, viz., the doctrines of the Protestant reformers, the political postulates of Gallicanism, and the ideas of enlightenment and liberal natural law. ${ }^{19}$

The Protestant Reformation exercised its influence in two ways: it repudiated the dogma of the sacramental character of matrimony, thereby opening the way for divorce, and transferred responsibility for the legal regulation of marriage from the Church to the State. The notion that marriage is "an external worldly thing, subject to secular jurisdiction, just like dress and food, home and field," as Luther expressed it, ${ }^{20}$ did not, of course, mean indifference on the part of the Church toward marriage and sex morals, just as the Church would not be completely indifferent toward morals in business or any other field of life. Christian princes and authorities should also be guided in their regulatory activities by Christian principles, as expounded by the theologians; but to establish and enforce any such

${ }^{18}$ A.D. 1563 .

${ }^{10}$ As to the following, see Martin Wolff, in Theodor Kipp and Martin Worff, FaMiLienrecht 9 (7th ed. 1931); Esmein, La jurisdiction de l'église sur le marriage en occident, ${ }_{4} 4$ NouverLe Revue HISTORIQUE DE DROIT 173 (1890).

${ }^{20}$ Von Ehesachen (1530), 30 Martin Luther's Works, Part III, 205 (Weimar ed. 1910). 
regulation was to be their task and responsibility rather than the Church's, which was in almost all Protestant territories closely linked, however, to the temporal power, either under the Lutheran or Anglican system of princely caesaropapism, or under the Geneva or Zurich patterns of the Calvinist or Zwinglian city republics. Not everywhere, it is true, were marital causes handed over to the regular civil courts. In England they remained in the jurisdiction of the ecclesiastical courts, which had become courts of the King however, and in many other places they were to be handled by the consistories, through which the church government was carried on by the princes, city or cantonal councils, or other wielders of secular power. Soon we find that practically everywhere outside of England the consistories came to grant permission to a husband to repudiate an unfaithful wife, and every now and then to allow a wife who had been abandoned by her husband to enter upon a new marriage. There also grew up a practice among Protestant rulers and councils of free cities in the exercise of their sovereign powers to grant a subject the privilege of having his marriage terminated. Originally regarded as a matter of grace to be exercised according to free discretion, this practice developed in some places into a fixed routine under which a divorce would be granted almost as a matter of course in those cases in which adultery, cruelty or desertion could be proved. This institution of executive divorce by the sovereign became the basis for that practice of divorce by the legislature which once played a considerable role in England and in this country ${ }^{21}$ and which still survives in Canada for the province of Quebec, ${ }^{22}$ and it also was the starting point for the practice of divorce by administrative agencies as it presently exists in Denmark, Iceland, and Norway. ${ }^{23}$

With the establishment of absolute and all-comprehensive state power, as it found expression in the newly developed concept of sovereignty, the notion that marriage constituted a topic of concern to the secular power of the state, and thus a fit subject for its legislation, could not remain limited to the Protestant countries. In France this notion assumed particular strength in the course of that policy of Gallicanism which was aiming at establishing the Church of France, the ancient Gaul, as a special body within the all embracing Church of Rome, and also establishing for his Catholic Majesty, the King of France, certain ecclesiastical powers independent of the Pope. This policy, which was eagerly followed by other Catholic monarchs, resulted in the practical transfer of jurisdiction in matrimonial causes from the ecclesiastical to the secular courts and also in a similar transfer of legislation in marriage matters-legislation which, while generally tending to avoid conflict with the tenets of the Church, still was in the form of regulation by the secular rather than the ecclesiastical power. ${ }^{24}$

The break with the spirit of the Church's marriage law was brought about by

${ }^{21}$ Cf. Maynard v. Hill, I25 U. S. 190 (I888).

22 These legislative divorces are granted by the Dominion Parliament.

${ }^{23}$ Denmark: Law of June 30 , I922, Conclusion and Dissolution of Marriage, $\$ \$ 54,65$; Iceland: Law of June 28 , I92I, $\$ \$ 5 I-8 I$; Norway: Law of May 15, I9I8, c. $5, \$ \$ 43,44,76$.

24 Jean B. Brissaud, A History of French Private Law 89 (Howell's transl. ig12); Esmein, supra note 19, at 201 et seq. 
that legislation which took its inspiration from the philosophy of enlightenment and individualism which had grown up from the sixteenth century to find its classical expression in the eighteenth century through the French Philosophes, Locke, Kant, and the jurists of the school of rationalist natural law. ${ }^{25}$ There was opposed to the ancient doctrines of Christian marriage, as it had been developed by the Church and the theologians both Catholic and Protestant, the inalienable right of the individual to the pursuit of happiness. This right had clearly to include the freedom of the individual to shake off the tie of an unhappy marriage and to pursue marital happiness with a new partner. Giving a new meaning to the Protestant Reformers' view of marriage as an institution of this world rather than a sacrament, it was now declared to be a civil contract about which natural law established that it could be freely dissolved at any time, and especially when it turned out to have failed in its end of bringing happiness to the parties.

The first country in which these new tendencies were to reshape marriage legislation was Prussia, ${ }^{28}$ whose King, Frederick II (the Great), constituted the very prototype of the "enlightened" eighteenth century monarch. His decree of $175^{2}$ was the first legislative act in modern Europe by which marriage was declared to be a private affair. That pronouncement was not to be taken quite literally, however; the state did in no way intend to abandon its regulatory and judicial powers in matters of matrimony, but divorce was admitted not only for cause but also upon the basis of mutual agreement and even in the case of unilateral "insuperable aversion." No clearer and no more consistent expression has ever been given to the postulates of modern individualism than in this decree of an absolute king, promulgated exactly two hundred years ago. The provisions of Frederick's decree were taken over in his successor's General Code of I794, and they remained the law of Prussia until the trend was reversed one hundred years later under the influence of the Catholic Church. But at the time the trend had spread into the neighboring countries. Among those to be influenced was Austria under its "enlightened" rulers, Maria Theresa and her son Joseph II. ${ }^{27}$ While in that predominantly Catholic country the Church was strong enough to prevent the abolition of its matrimonial system with respect to Catholics, it could not prevent the emperor from establishing an entirely new system for his non-Catholic subjects and even from recasting the matrimonial law of the Catholics as state law which, while in its contents conforming to the demands of the Church, was no longer an act of its, but of the state's, legislation. Until its absorption into the Greater Germany of Adolf Hitler, Austria preserved the peculiar feature of different, state-enacted marriage laws for the different religious denominations. For Catholics, divorce remained excluded, but to Jews it was to be granted upon the mutual agreement of the parties, and in the case of non-Catholic Christians it was allowed

${ }^{25}$ Cf. SchöN, GöttTinger Festgabe für Regelsberger 185, 207 (Ig0r).

${ }^{20}$ Allgemeines Landrecht für die Preussischen Staaten, $\$ \$ 670$ et seq. II, I.

${ }^{27}$ Cf. 2 Armin Ehrenzweig, System des osterreichischen allgemeinen Privatrechto 8, 96 (2d ed. 1924). 
even for unilateral insuperable aversion, provided a judicial separation had first been obtained.

In France, ${ }^{28}$ the center of enlightenment thought, the Church's marriage system was swept away by the Revolution, whose first Constitution declared marriage to be a civil contract. The law of I792, which established clear rules after the uncertainty of the early revolutionary outburst, expressly admitted divorce upon mutual agreement, although hedged in by time-consuming formalities; but the law of the Revolution did not go quite so far as that of the King of Prussia; it did not admit unilateral divorce in the case of insuperable aversion. Helped by the powerful impetus of the French revolution and the French armies, the ideas of liberalism and enlightenment spread over large parts of the Western world, where they found expression in those secular marriage laws which the governments came to substitute for the old system of regulation by the church or churches.

In these new secular laws the spirit of liberal individualism and secularism found expression ( $\mathrm{I}$ ) in the admission or, in places, the compulsory provision, of a secular ceremony for the conclusion of marriage, (2) in the reduction of the scope of the prohibited degrees, (3) in the admission of religiously mixed marriages, (4) in the elevation of the status of the wife from that of an inferior to that of an equal partner, and (5) although with much vacillations and variations, in the admission of at least some possibility of divorce, either solely for cause or, as in the bold legislation of the eighteenth century, upon mutual consent or even unilateral desire. $^{20}$

These trends required a long time to become effective everywhere; indeed, today not even secularization of marriage has been carried through universally. In Russia and the other countries of Eastern Europe the religious marriage laws of the Orthodox Church as well as of the minority religions remained in effect as such and matrimonial causes continued to be handled by ecclesiastical authorities until the revolutionary events of IgI7 and the subsequent spread of their influence. In the countries of the Near and Middle East, with the exception of Turkey, where marriage was secularized and westernized by Kamal Atatürk, ${ }^{30}$ regulation of matrimony and jurisdiction in matrimonial causes still belong to the spheres of the religious bodies and, except in India. and Pakistan, of the ecclesiastical courts, so that both the laws and the courts are different for Moslems, Jews, and Orthodox, Catholic, Armenian, Maronite, and other groups of Christians. However, under the general impact of Western ideas and an increasing uneasiness at the irregularities resulting from the differences among the religious laws, the secularizing trend has come to make itself felt even in the Islamic world. It has met there, however, with strong resistence rooted in the Islamic revival. Quite recently the clash of these ideas has resulted in serious disturbances and a drawn-out strike of the bar in the Republic of Lebanon.

\footnotetext{
${ }^{2 B}$ See note Io supra; Brissaud, op. cit. supra note 24 .

${ }^{20}$ See note 7 supra.

${ }^{30}$ Civil Code of Feb. I7, I926, arts. 82 et seq.
} 
In the West, too, the twin trends of secularization and liberalization could not run their course without encountering opposition. Next to divorce the most controversial problem was that of the formalities required for the conclusion of a valid marriage. ${ }^{31}$ That no marriage could be concluded without some formal ceremony became axiomatical after the Council of Trent in all Western countries except those in the sphere of the English common law. It was equally axiomatic that the ceremony had to be a religious one. Variations existed only with respect to the permissibility of the celebration of marriages in ways other than those provided by that church which happened to be the established one in the territory in question. Would dissenters be compelled to choose between marrying before the minister of a hated "false" church and living in sin, or would they be allowed to follow the ceremony of their own denomination? Passions similar to those engendered by this question were aroused again when, after the model of France, secular governments began to insist that marriages be concluded exclusively in secular form and before a secular official. The hardship was more apparent than real, however, because even in those states where "civil marriage" was made compulsory to produce the civil effects of marriage, parties were left free to go through a subsquent religious ceremony of the denomination of their own choosing. The problem was avoided completely in those countries in which, as in practically all American states, ${ }^{32}$ the use of a civil ceremony was admitted as optional rather than prescribed as the only possible form of entering upon a valid marriage. That a secular ceremony should at least be permissible was a compelling demand, however, of modern secularism, which had to be granted even in a country as staunchly Catholic as Spain. ${ }^{33}$

Until the end of the nineteenth century, it seemed as if the progress of secularism and liberalism would be irresistible and as if it were only a question of time until they attained universal domination. However, since the end of the First World War it has become apparent that a counter-current has achieved sufficient strength to stem and, in some places even to reverse, the tide. As a matter of fact, already at the end of the nineteenth century this counter-trend had been strong enough to prevent the inclusion of the liberal rules of the old Prussian Code in the new Civil Code which took effect in Germany on the first of January, Igoo, ${ }^{34}$ superseding thereby the earlier laws of all the component parts of the Reich. Divorce upon mutual agreement and upon the ground of unilateral insuperable aversion were abolished. Apart from the case of incurable insanity, divorce was to be admissible

${ }^{31}$ Cf. Wolf, stipra note 19, at $\mathrm{II}$ : A. Bergmann, in 2 Schileglberger, Rechtsvergletchendes HANDWOERTERBUCH 727 (I929).

32 The only exception is constituted by Maryland, where a religious ceremony is compulsory (Mo. ANN. CODE GEN. LAws art. 62, \$4 (1939)).

${ }^{33}$ Civil marriage was made compulsory by the Law of June 18,1870 , but religious marriage was reintroduced in 1875 . By the Civil Code of July 24, 1889 , religious marriage was maintained as compulsory for Catholics, while civil marriage was provided for non-Catholics. By the Spanish Riepublic civil marriage was again made compulsory (Ordinance of Nov. 3, 193r), but the preRepublican law was restored by the Franco Regime (Laws of Mar. 4, 1938 and Sept. 23, 1939).

s4 Civil Code of Aug. 18, [1896] ReichsgesetzblatT I95. 
only in the case of adultery, desertion, or other misconduct, including, however, the indefinite and stretchable category of "blameworthy conduct rendering married life unbearable to the other partner."35 Under the interpretations which were placed upon this omnibus clause by the courts, especially those of larger cities, the step backward which the Code of 1896 constituted as against the law of $175^{2}$ / r794, was not very considerable. Sensational, however, was the development which took place under Mussolini's regime in Italy. Ever since Italy's unification as a nation in the nineteenth century, secular liberalism and conservative Catholicism had been locked there in an undecided battle. The newly created state had assumed the role of legislator in the matrimonial field, had liberalized the marriage laws in various respects, had established civil marriage before a state official as the only legally effective form of concluding a marriage, and had assumed in its own courts full jurisdiction in all matrimonial causes. Catholic sentiment was too strong, however, to allow the abandonment of the principle of indissolubility of marriage. In the Civil Code of I865, divorce thus remained excluded. In I929, when Mussolini was striving for an understanding with the Church, marriage jurisdiction was handed back to the Church in the Lateran Treaty, which also re-established as the regular form of marriage its conclusion before the Catholic priest in accordance with the Catholic rites. The possibility of a civil ceremony was retained as optional, and there was also introduced the possibility of marriage being celebrated before the minister, and in accordance with the rites, of any other officially admitted denomination. However, as to Catholic marriages, which constitute the overwhelming majority, the Church was handed back not only the ceremony but also jurisdiction in matters of nullity and separation. This arrangement ${ }^{36}$ has survived the collapse of Fascism and thus the Church's highest tribunal, the Sacra Romana Rota, is still the supreme court in matrimonial causes for Italy. The Italian step was later followed in Austria, ${ }^{37}$ where it was in turn undone by Hitler, ${ }^{38}$ and in Franco Spain. ${ }^{39}$ There has thus set in a reversal of the former trend of secularization of the law of marriage, which has found expression not only in the return of jurisdiction in matrimonial matters to religious authorities but also in a renewed emphasis upon greater strictness, especially with respect to divorce.

This reversal of the liberal trend has not been limited to countries of strong Catholic or Islamic influence, but has found expression also in communities which have been guided by considerations of a purely secular character, such as NationalSocialist Germany or the Soviet Union. In the Third Reich of Adolf Hitler the reform was aimed particularly at strengthening judicial discretion. Where divorce

as Id. $₫ 568$.

30 It was codified in Articles 79 et seq. of the new Civil Code of Mar. I6, 1942.

${ }^{37}$ Concordate between the Holy See and Austria of June 5, x933; Austrian Law of May 4, I935.

${ }^{38}$ Marriage Law for Greater Germany, of July 6, I938, [1938] ReichsgeseTzBLATt I, 807. It has been "temporarily" kept in force in Austria after the separation from Germany in 1945.

${ }^{30}$ Divorce was also abolished in 1932 in Bolivia (Law of April 15, 1932), where it had been admitted in the Civil Code of Oct. 25, 1850. 
for cause had before been a matter of right, it is now to be refused where it would "not be morally justified."

In Russia the Revolution of 1917 had brought a shift from the ecclesiastical marriage law of the Orthodox Church to a system of radical secularism and individualism. Under the Czarist regime a religious ceremony was indispensable for the conclusion of a marriage, and as to divorce, jurisdiction was vested in the religious bodies, especially the Holy Synod, which would not grant a divorce on any ground other than adultery, and then only in proceedings of extreme expensiveness and long drawn out duration. At first under the Bolshevik regime, ${ }^{41}$ both the conclusion and the termination of a marriage were to be strictly private matters. No ceremony of any kind, religious or secular, was to be necessary for contracting a marriage, and no public agency's decree or cooperation was to be required for a divorce. This shift was in keeping with those ideas which Engels had expressed in Marxism's classical work on the family, ${ }^{42}$ in which the need for all restrictive sex regulation was said to have originated in man's cardinal sin, individual property. Bourgeois marriage was described as a primarily monetary affair, which was supplemented by prostitution and other immorality. As soon as property was collectivized, the need for restrictive sex legislation would disappear, as indeed the state and all law would wither away. Inequality of the sexes would no longer exist, and marriage, based on true and pure love and affection, would no longer need the support of any compulsory authority, be it ecclesiastical or governmental. The result of the application of this optimistic creed was a situation which in effect was the same as once existed in ancient Rome; both marriage and divorce were treated as matters of private concern exclusively. The utmost the state would do was to record them as a matter of evidence after they had been brought about by the individual parties', or, in the case of divorce, by one of the parties', own private act.

Today, thirty-five years after the Revolution, the situation in Russia is different. Marriage is required to be concluded before an official of the state and to be officially recorded, and no divorce is possible without the decree of a court. In order to obtain it application is to be made to the People's Court, which has to investigate the facts and to attempt a reconciliation of the parties. If the parties, or one of them, continue in their insistence upon a divorce, the case is certified to a higher court, where, after a hearing, decision is rendered either granting or deny-

${ }^{10}$ Control Council Law No. 16 (practically identical with the Marriage Law of 1938), $\$ 543,47$; cf. Schoch, Divorce Law and Practice Under National Socialism in Germany, 28 Iowa L. Rev. 225 (1943).

${ }^{1}$ On the development of the law of marriage and divorce in the U.S.S.R. see especially Sverdlov, Modern Soviet Divorce Practice, II MOD. L. REv. I63 (1948); and Note, Le mariage et le divorce d'après la législation actuelle de l'U.S.S.R., 2 Revue INTERnationsie de Droit Compare 347 (Ig50); furthermore, I Viadimir Gsovski, Soviet Civil Law: Private Rights and Their Background Under THE Soviet RegIME III (1948); 2 id. at 239; Gsovski, Marriage and Divorce in Soviet Law, 35 Gzo. L, J. 209 (1947); Wolff, Some Aspects of Marriage and Divorce Laws in Soviet Russia, 12 Mod. L. Rev. 290 (1949); Soloveitchik, Family Law and Inheritance Law in USSR, 15 U. of KAN. Ciry L. Rzv. 83 (1947).

\$2 Der Ursprung der. Familie, des Privateigentums und des Staats, 1884. 
ing the divorce. The statute does not list any "grounds" upon the proof of which plaintiff would be entitled to a divorce, but in all cases the decision is entrusted to the sound discretion of the court. In order to obtain a hearing the petitioner has to pay a fee of considerable magnitude, which is increased with every new divorce which he seeks to obtain.

From the sources available it is difficult to obtain a full picture of the Russian situation. Clearly, the courts have the power to refuse a divorce and to make it difficult to obtain one. It would be important to know how they are exercising their powers. This much is clear, however: marriage and divorce are no longer matters of purely private concern and again the state has reserved the last word to itself.

Quite likely the reintroduction of compulsory resort to the state is connected with the readmission of individual ownership in goods of immediate use and consumption as well as in savings and the re-establishment of a system of inheritance, testate or intestate, of such assets of individual ownership. In order to determine a property owner's heirs, it is necessary to have authoritative evidence of his marital status. However, the change of attitude toward divorce seems to have deeper reasons and to be connected with that emphasis upon discipline and order which has come to permeate Soviet life. ${ }^{43}$ The needs of the planned economy as well as military considerations no longer permit that freedom of the individual which inspired the early revolution and which now can be kept only as an ideal aim to be achieved in that indefinite time when, after the destruction of the last threat of imperialist capitalism, the period of transition will have ended and that of full communism begun. At least until then discipline is the duty and virtue of the Soviet citizen: discipline in labor, discipline in the fight for the proletarian fatherland, and discipline in his personal life. The trend is conspicuous in all walks of Soviet life-in education, in the arts, in literature, in legal theory, even in linguistics. In legal theory the doctrine of the laws' and the state's withering away has been abandoned as the necessity of not only continued but ever-increasing governmental regulation and police power became apparent; and in the field of language, Stalin himself has recently condemned theories which were apt to result in looseness of oral and written expression at the expense of clarity of communication and beauty of style.

If discipline and the ability to bear hardship are to be necessary for the Soviet citizen, these virtues must be developed in the family. Here we are meeting, indeed, the consideration which underlies all advocacy of a strict regime of marriage and divorce, not only in the laws of the Soviets but wherever discipline, order, and service to an idea are more highly evaluated than the "self-indulgent and egoistic" pursuit of individual happiness on this earth. The virtues which are needed in a

${ }^{43}$ On these trends see John Hazard's Introduction to the volume entitled Sovier Legal PhiLosopHy (195I); Fuller, Pashukanis and Vyshinsky: $A$ Study in the Development of Marxian Legal Theory, 47 Mich. L. Rev. II57 (I949); Harold J. Berman, Justice in Russia (I950); I Vladimir Gsovski, Soviet Crvil Law: Private Rights and Their Background Under the Soviet Regime 152 (1948). 
society of this kind are developed first of all in the family, and marriage is the crucible from which they emerge, as the parties are steeled in the overcoming of difficulties. Difficulties will indeed arise in every marriage, even the most harmonious. Spouses must overcome them and in so doing-in, so to speak, battling their way through to each other-they grow and mature in self-mastery, understanding, patience, and love-that is, in exactly those virtues which strengthen not only the coherence of society as a whole, but also each individual home in which children are growing up as the next generation. The ideals which underlie the old Christian approach to marriage can thus be justified upon a purely secular basis. However, they are effective only within a system of thought and attitude in which God, the nation, the proletarian community, or some other transcending end is placed above the individual as the ultimate value. They are not convincing to one who regards the individual and his happiness as the ultimate value and the state or society as no more than a means toward that end.

Which attitude one takes toward marriage, its role in human life, and its duties, thus depends upon his position toward ultimate values. During the late eighteenth and the nineteenth centuries that individualism which had grown up and developed since the Renaissance in contrast and opposition to the transpersonalism of traditional Christianity, had assumed sufficient vigor to transform attitudes toward marriage and divorce almost everywhere in the Western world. How far the changes would go depended, however, in every country upon the balance between the contesting forces. Not only in some of the Catholic countries, but also in places where Protestant Christianity was deeply rooted, the pace of modern secularism and individualism was slowed and, consequently, was not allowed to bring about radical changes in the structure of marriage. A new opposing element has appeared through the rise of modern secular collectivism and totalitarianism, which also had to oppose or undo individualist transformation of the marriage laws.

The strength of each of these opposing forces does not, of course, depend solely upon the numerical relations in which the two basic positions are distributed over the populace. Many, or perhaps most, of its members have not formed their ideas with articulate clarity. They not only are undecided in their own attitudes, but often ambiguously vacillate between postulating strictness for the community and yet expecting accommodation of their own individual desires. Decisively, however, the power relation depends in each country upon its political structure, which may well give preponderance to a minority group. In those democracies in particular where political weight and influence depend upon organization, it is easier to be organized and thus to be influential for groups united in the strong feelings of religions or other transpersonalisms than for individualist liberals. The results of these often unstable relationships have been manifold compromises finding expression not necessarily in the official law but in contradictions between a strict official law of the books and an actual practice of an entirely different character. In the Catholic countries of the Latin part of the world, the strictness of the marriage law 
has been tempered through the more or less open acceptance of the mistress system. In democracies it seems that it has been easier for conservatism to dominate in the legislature than in the courts. The latter, being closer to the pressures of individual parties and their attorneys, and unable to investigate, as the law would prescribe, the immense mass of cases brought before them, have more easily yielded to individualistic demands which have spread through the population without finding organized expression. The courts have thus come to tolerate collusive practices through which consent divorces can be easily obtained in spite of their reprobation by the official law. Such practices have grown up in a good many places, but quite especially in this country, where unorganized trends, even of large numerical strength, are finding it particularly difficult to influence the legislatures. This discrepancy between the law of the books and the law in action, which we find in so many states, has, through its tolerance or promotion of collusive practices and perjury, developed into a serious threat to the morals of the bar and the respect for law among the public. There seems to be little chance for a remedy, however, as long as those individualist pressures which are at work in our present American society are unable to find adequate expression in the legislatures, so that legislative action is more likely to run counter to than to satisfy those popular demands which either cannot or do not dare to make themselves felt. 